Yanyk $O$. The main principles of neuroscience in the context of a "brain-friendly"...

UDC 81.378

DOI https://doi.org/10.24919/2308-4863/35-8-44

\author{
Oksana YANYK, \\ orcid.org/0000-0002-5899-7179 \\ Lecturer at the Department of the Ukrainian Studies \\ Bogomolets National Medical University \\ (Kyiv,Ukraine) oksanayanyk81@gmail.com
}

\title{
THE MAIN PRINCIPLES OF NEUROSCIENCE IN THE CONTEXT OF A "BRAIN-FRIENDLY" APPROACH TO TEACHING FOREIGN LANGUAGES
}

This article considers and systematizes the basic principles of neuroscience and points to their practical application in teaching foreign languages in higher education in the context of a new "brain-friendly" approach based on the concept of neurolanguage coaching. The basic principles of neuroscience, which are constants in neurolanguage, are also generalized. The examples of the usage of neuroscientific principles are given, which become key principles in the formation of a modern approach to teaching foreign languages. The concept of "neurolanguage coaching" is revealed and how the understanding of our brain can serve to optimize the learning process.

The relevance of the topic is due to the fact that only understanding how "our brain actually learns" gives foreign language teachers the opportunity to improve the level of foreign language teaching and make the teaching process naturally effective.

Neuroscience, and mainly practical research in this area helps us to better understand the problems that arise when teaching a foreign language both in a group (in the classroom) and individually with each student. Accordingly, knowing exactly how our brain works, "how it learns" gives us the opportunity to form a so-called "brain-friendly" approach to teaching a language.

The latest research in this area, which we relied on in our article is the study of the founder of the method "Neurolanguage coaching" Rachel Paling, neuroscience research "language socialization" by M. Lieberman, the work of Professor C. Kelly, practical research conducted at the University of Southampton and others.

Generalizing the key principles of neuroscience and applying them in practice in the context of a "brain-friendly" approach, gives us the opportunity to improve our teaching skills and make our own discoveries in the field of teaching.

Key words: neuroscience, "brain- friendly" approach, language socialization, neurolanguage coaching, motivation.

Оксана ЯНИК,

orcid.org/0000-0002-5899-7179

викладач кафедри україністики

Начіонального медичного університету імені О. О. Богомольия

(Київ, Україна) oksanayanyk81@gmail.com

\section{ОСНОВНІ ПРИНЦИПИ НЕЙРОНАУКИ В КОНТЕКСТІ «ДРУЖНЬОГО ДО МОЗКУ» ПІДХОДУ У ВИКЛАДАННІ ІНОЗЕМНИХ МОВ}

У изій статті розглянуто та систематизовано основні принципи нейронауки, вказано на їхнє практичне застосування під час викладання іноземних мов у вищих навчальних закладах у контексті нового «дружнього до мозку» підходу, який трунтується на концепиї нейромовного коучингу. Також узагальнено основні принципи нейронауки, щцо є константами в нейромові. Наведено приклади використання нейронаукових принципів, які стають ключовими засадами у формуванні сучасного підходу до викладання іноземних мов. Розкрито поняття «нейромовний коучинг» та як розуміння нашого мозку може служити. для оптимізачї навчального процесу.

Сьогодення ставить багато викликів педагогам, а особливо викладачам іноземних мов. Змінюються не лише підходи до викладання мов, а й самі студенти, які стають більш свідомі практичного значення вивчення іноземної мови та переваг, які вони отримують у майбутньому, добре володіючи англійською чи то іншою важливою іноземною мовою. Актуальність теми зумовлена тим, щцо розуміння того, як насправді «вчиться наш мозок», дає змогу викладачам іноземних мов покращчти рівень викладання іноземних мов та зробити процес викладання невимушено ефективним.

Нейронаука, а власне практичні дослідження в цій галузі допомагають нам якнайкраще зрозуміти проблеми, щчо виникають у нас під час викладання іноземної мови як у групі (в аудиторії), так $і$ індивідуально з кожним студентом. Відповідно, знання того, як саме праџює наш мозок, «як він вчиться», дає нам змогу сформувати так званий підхід, який $\epsilon$ «дружнім» щзодо нашого розуму ("brain-friendly approach).

Найновіші дослідження в иіий галузі, на які ми спиралися в нашій статті, - це дослідження засновниці методу “Neurolanguage coaching” Рейчел Пелінг, нейронаукові дослідження «мовної соиіалізації» М. Лібермана, роботи професора К. Келлі, практичні дослідження, проведені в університеті Саутгемптона та ін. 
Узагальнення ключових принципів нейронауки та застосування їх на практииі в контексті «дружнього до мозку» підходу дає нам змогу покращувати свою викладаџьку майстерність та робити власні відкриття у сфері викладання.

Ключові слова: нейронаука, «дружній до мозку» підхід, мовна сочіалізація, нейромовний коучинг, мотивація.

The problem statement. Today, one of the biggest problems of the higher education system is teaching foreign languages to students, which can have various reasons: the peculiarities of the future profession, the language of the country in which they study, raising the cultural level and so on. Therefore, the question is how to promote this process, what methods to use to inspire students in educational programs to learn a foreign language (English, Ukrainian, French, Italian, etc.) is extremely relevant today.

Research review. In our article, we maintain an analysis of the process of teaching a foreign language in the context of the "brain-friendly approach" - a new approach based on the concept of neurolanguage coaching (Rachel Paling's term) and the practical application of neuroscience. The latest research in this area, which we relied on in our article is the study of the founder of the method "Neurolanguage coaching" Rachel Paling, neuroscience research "language socialization" by M. Lieberman, the work of Professor C. Kelly, practical research conducted at the University of Southampton and others.

The aim of this article is to systematize the basic principles of neuroscience and point to their practical application in teaching foreign languages in higher education. The given examples of using the principles of neuroscience become the key principles in the formation of a modern approach to teaching foreign languages, where the vector of teacher as a transmitter of knowledge changes into the plane of coach, and this concept, which came from sports, we gradually introduce into the educational sphere.

Presentation of the main material. So what exactly is neuroscience? In her book "Neurolanguage coaching. Brain friendly language learning" R. Paling gives insights of this notion. She explains that neuroscience is the study of the development of nervous system, as well as its structure and what it does. Neuroscience has advanced a lot since 1950s. New technology like fMRI scans (functional magnetic resonance imaging) give us an opportunity to see "the brain in action". The most fundamental cells of our nervous system are nerve cells called neurons. There are about one hundred billion nerve cells forming between a trillion to even quadrillion neural connections. "Neurons do actually communicate directly with one another sending messages in the form of electrochemical signals or impulses, but neurons do not actually touch each other as there is always a space between them called a synapse. In very simple terms, cell-to-cell communication occurs when an action potential travels down a neuron to the synaptic gap to connect with other neurons or other cells" (Paling, 2017: 38). "Whenever there is brain activity, there can be millions of neurons firing together at the same time and this firing produces electrical activity, which can be measured or monitored by an electroencephalogrphy, or EEG for short. Neurons connect to create incredibly vast and intricate neural networks. Our neural networks or maps are in fact our personal internal representations of the external world. Interestingly, wherever we focus our attention and energy, those brain maps will become more ingrained or embedded into long-term memory" (Paling, 2017: 39). Our brain is plastic and not static. "Neuroplasticity is the ability of the brain and nervous system to change structurally and functionally in response to its experience". (Paling, 2017: 40).

One more interesting discovery was made in 1998. Scientists discovered that human brain produces new nerve cells into adulthood (Gage, 1999).

The research in neuroscience gives us ground to encourage learners at any age. And as educators we should always remember each learner's brain is unique.

Nelson Mandela's said "If you talk to a man in a language he understands, it goes to his head. If you talk to him in his language, it goes to his heart."

Concerning the methodologies of teaching foreign languages, the most popular over the last half century are the following: the direct method, audio-lingual, suggestopedia, the silent way, task-based language learning, the lexical syllabus, grammar-translation, the structural approach, total physical response (TPR), community language learning immersion, the natural approach, communicative language teaching (CLT) (Richards, 1986).

Looking at the traditional picture behind teaching one has a teacher who passes on language knowledge and is fully portrayed as the active player who is responsible for the transmission of the knowledge. We also have a learner who receives knowledge and is portrayed as the passive player when listening and absorbing the information, becoming active when they speak or write. Thus, a teacher is the central focus and the controller. A teacher guides the learner through the learning material, using directional and 
Yanyk $O$. The main principles of neuroscience in the context of a "brain-friendly"...

instructive means. So, even though the teacher transfers their knowledge, the learner knows the language but is not able to put it into practical usage. Typically the teaching process spin around practical books or a certain set of materials is being used. The relationship between teacher and learner can be impersonal and distant. A teacher may totally ignore the sociocultural character of the learner, therefore the learner may sometimes find it hard to relate to the learning (Webinar, 2020).

In the 1970s the "communicative approach" (communicative language teaching - CLT) developed. This approach is based on thinking over the way language works in real life and we use the language and how we should take it into consideration when teaching languages.

The creator of the concept "Neurolanguage Coaching" says that we are shifting to the era in which we start to see how understanding our brains actually serves to optimise the learning process (Paling, 18). She states that Neurolanguage Coaching follow on from communicative approach "with the added dimensions of the coaching approach and the brain-friendly conversations derived from the practical application of the principles of neuroscience" (Paling, 2017: 29).

Professor Curtis Kelly remarks that neuroscience has great potential on language learning. We simply cannot understand the complex neurological processes of "language" or "learning" without it. Traditional sciences such as Linguistics and Psychology give us the vision from the outside, but neuroscience takes us inside. It provides us with an understanding of attention, motivation, engagement, logical processing, developmental change, emotion, character formation, sensory input, learning disorders etc. He resumes that neuroscience might make us better teachers, but it won't cause a revolution in teaching. Firstly, it's because it doesn't represent radical change. C. Kelly states that we already knew things like: personalization increases attention, sleep and physical exercising are needed for good mental functioning, and also adding a bit of humour or novelty gets attention. We get all of these from experience, training, and especially intuition, though the last one is hard to defend. Consequently, we are inclined to underestimate all-important principles of learning and prioritize more concrete aspects of teaching, whether those are explaining verbs tenses or having chapter covered. What neuroscience does is explains the specific mechanisms of those intuitions of ours. "It gives us the science for those things from the dark area that we have always known, but resisted trusting" (Kelly, 2017).
Globalisation and computerisation have had, and continue to have, a great influence on language teaching. There is also a question concerning the need for social interaction unlike the computerised interaction. From neuroscientific research such as Lieberman's work, we know that "being socially connected is our brain's lifelong passion" (Lieberman, 2013). His research suggests that we tend to remember information when taking it socially. And we know that to learn effectively our brain needs real and personal interactions, generating and sharing the information with others (Paling, 2017: 30). In one study, two groups of students were given a reading task. One group was told that they would be given a test on it, while the other one was informed that they would have to teach it to someone else. Of course, two groups were given a test afterwards, but interestingly the latter one did better. Education is generally missing this huge potential, as human beings are driven by their social needs (Kelly, 2020). A professor of English at Kansai University in Japan adds that we as coaches and language teachers are aware how powerful pair or group work can be. Allowing young people to communicate with each other satisfies their deep internal need to "make friends". And we know that existence of friends is critical for their well-being, research shows it decreases the likelihood of depression and increase the likelihood of academic success (Kelly, 2017). He notes that our brain is a multiprocessor and acts more like a committee than a king or queen. Approximately 50 processing centers are usually engaged in separate tasks. To put it in other words, the amount of language we keep is connected with how much of our brain we use to process it. Professor C. Kelly points out: "Deep processing leads to deep learning: thousands of neurons reaching out and linking up. These new channels of connections form when we experience multi-sensory input, when we have to figure something out rather than being told, and when use what we learn. These kinds of broad channels do not form when we sit passively in class listening to someone go through a list of language rules that we have little interest in" (Kelly, 2017: 27). So, the aim of teaching should be to make our learners as active as possible. He emphasizes the need for us to develop brain compatible teaching practices that focus more on how language is learned and less on the very structure of language. We should also assume that language cannot be separated from emotional, developmental and human needs of our students. "The language we teach must be meaningful. It must be relevant. And it must be taught in ways that make processing deeper, learning more active, and learners more emotionally engaged" (Kelly, 2017: 28). 
Professor Ros Mitchel adds more view on classrooms as social settings, and as social contexts in which language knowledge is mutually formed by dialogue between a teacher and students, and also among the students themselves. Thus the term language socialisation has been created. So, in the classroom we have to think of a social group or community. The question will be in what sense the classroom is a community. Obviously, classroom members don't live together and they don't spend their free time together, but while in the classroom, they have come together with their teacher for a common aim which will hopefully help them jointly to develop their language knowledge. So the learners are moving together from being less skilled to being more skilled in a particular language. And of course the classroom cannot function without active participation of the students and the teacher. If the students are alienated, learning won't take place. Researchers Lave and Wenger called the classroom community a community of practice, where many of the participants are shifting from quite marginal posirions (in our case as language users) to becoming more and more skilled, and consequently can play greater parts to make bigger contributions to the life of the community of practice (Online webinar, 2020).

Having outlined different points of view, we can resume that a 21century language teacher is transforming into a coach, whose task is not only to transmit the knowledge to students, but also to create a brain-friendly approach based on the principles of neuroscience. To task of a neurolanguage coach is to create the classroom ground for social interaction and to monitor the process of active participation of all the members of learning process, setting the tasks which will launch deep processing, resulting in deep learning.

Very important and interesting question which was raised by Rachel Paling is whether we can speak about "perfect learning state". The answer is yes, we can. And the crucial components of this state are: intention and motivation, which are interconnected.

Alasdair Archibald (Online course, 2015) also points out motivation as a key factor in how fast or effectively you learn anything, including languages. Why do we try to learn a language? Do we want to be accepted into a community? Do we simply want to pass an exam? Do we want to have better job perspectives after graduation? There are more ideas what can motivate us to learn a language. An interesting survey was conducted by University of Southampton about factors that influence how well we learn languages. The question was "What do you think is the most important factor?" The possible options were the following: age, gender, natural ability, peer support, motivation for learning, universal language knowledge and effective teaching. Out of 4597 respondents, $3416(74,3 \%)$ chose the option "motivation for learning" (Online course, 2015).

R. Paling also states that without motivation information won't be easily retained in the brain. She comes up with three types of coachee:

1. The "yes, motivated"

2. The "not motivated, but there is something in my life which would motivate me to learn the target language"

3. The "not motivated and nothing in my life which would motivate me to learn the target language.

Thus, we can assume that motivation can be called a key to success in language learning. And as educators we should help our students to find their motivation and to keep it up along the way of mastering a foreign language. Of course we are lucky if the majority of our learners are motivated, or at least could find something in their lives which can motivate them to learn a foreign language. We can also encourage the change in mindset, especially when we hear from our learners that they have struggled a lot with learning a language, but failed to learn it.

Professor Kelly states that learning, in simple terms, means memory formation. And the first step in forming any kind of memory is paying attention. With hundreds of pieces of data which enter our sensory system at any given moment, we must filter out the piece that is important and then send it on for further processing. "This is handled by the reticular activating system, located in the brain stem, but which is also connected to everywhere else. This filter passes on sensory information related to personal relevance, recent executive thinking, and novelty, among other things" (Kelly, 2017: 89). As language teachers, we find the brain's sensitivity to personal relevance particularly important. Thus, the advantage should be taken more in materials development.

- Rachel Paling summarises seven underlying principles of neuroscience which are constants within the Neurolanguage (Paling, 2017: 89):

- A constantly calm brain state is absolutely essential.

- Motivation is crucial for optimal learning.

- Ensure the learner's attention.

- Get the learner into that "just do it" brain. This means that the subconscious programs of the language take over and stimulate the language to start to flow naturally.

- Chunk it down! Whether this refers to the process of language learning or the mechanical grammatical breakdown of the language itself. 
Yanyk $O$. The main principles of neuroscience in the context of a "brain-friendly"...

- Constant provocation to connect target language to native can greatly enhance the language learning process.

- Knowing about our own brain and respecting its nature as a "creature of habit and subconscious programmer" will greatly assist our learner to get to know his / her brain.

All of us know that stories are powerful teaching tools. And here we also have the explanation why, from neuroscience. The research shows that in term of retention information delivered in stories is better learned than through other means, such as explanations, lectures, etc. As we could expect it is because the stories are interesting, but the research from University of California brings unexpected results. The familiarity and interestingness had a small effect on the speed of retention. So, there is something special about the narrative format, regardless of the content (Kelly, 2017: 12). And not only the format, but also the format what affects the brain. And we will definitely ask why the narrative organization where events happen one after another have such a great impact on learning. "A story, if broken down into the simplest form is cause and effect. And that is exactly how we think. We think in narratives all day long, no matter if it is about buying groceries, whether we think about work or our spouse at home. We make up (short) stories in our heads for every action and conversation" (Wilson, 2002: 1). So, our brains are built to remember things which are important to us. And in this case stories are important because they are encapsulated experience (Kelly, 2017: 13).

Another crucial finding in neuroscience, about which the professor mentions, is exercising. We tend to associate it with general health rather than brain function. But neuroscience is telling us that it is critical for the latter, and mainly because of blood flow (Kelly, 2017: 14).

Sadly, many of us still cling to the idea that more regular class time is what learners need to pass tests and that physical education classes are an "extra". Now we should be aware that to optimize brain function we need to get our students out of their seats every half hour or so. It doesn't mean of course that we have to conduct physical exercises in class, but several changes can be much beneficial. These could be as following: "a) have students come to the front to get the quizzes and handouts, instead of passing them out; b) when handing papers in, have them bring them to you instead of passing them forward; c) instead of just raising hands to answer questions have students all stand up and those who do not know the answer sit down; d) have them do pair work standing up. A little moving benefits student energy, mood, and cognitive ability. It improves learning" (Kelly, 2017: 15).
Summing up the above said, to make the most of our classes, we should first of all draw the attention of our learners with some kind of information that is of their personal relevance. As an example we can take the first class of students who start learning a foreign language, but being multi-cultural, coming from different countries. Instead of simply telling them about the target language they are going to learn, we can build a short conversation involving the questions related to their personal experience of learning languages and their native tongue as well. "What is your native language?" "Is your language hard or easy to learn?", "How many languages do you speak?", "Do you think it is easy to learn your language?". While asking these questions we could set our learners into good learning state, because the questions are easy to answer and they make students relate to their personal experience. Meanwhile, we can smoothly move on to setting goals, finding out the motivation, and the type of motivation they have. Backing on this first class we can furthermore organise our ongoing classes using the brain- friendly teaching techniques mentioned above.

Continuing with a brain-friendly approach in teaching, let's have a closer look at delivering grammar through brain-friendly conversations. The founder of neurolanguage coaching in one of the chapters of her book describes the delivery of any grammatical material through very quiet, brain-friendly coaching conversation. "In this way, the coach avoids any negative threat response from the coachee and, in addition, enables and facilitates immediate connections and associations, as well as the instant application of the grammar in spoken language". She created her PACT PQC model which is a pathway for the coach to conduct these quiet conversations. In the following model: P - Placement, A - Assessment, $\mathrm{C}$ - Conversation, T - Teaching, PQ - Powerful Questions, C Clarification (Paling, 2017: 143).

Placement in other words is signposting language. She points out that it is very important to indicate exactly what part of grammar we are talking about at any given time and a coach should have a clear map of where they are and where they are taking that particular grammar conversation. He / she must signal this map all along the way (Paling, 2017: 145).

Assessment component means, as coaches we need to be aware and find out where the coachee is with his / her understanding and ability to express what he / she knows. We could also include here a question relating to how this particular grammar part compares to the same grammar part in the native language of the coachee, simply to hear how the learner relates and associates (or not) the target 
language grammar area with the native language area (Paling, 2017: 145-146).

Speaking about conversation here the coachee is involved in conversation concerning the real life and personal situation to practise the grammatical material that is being explained. This helps a learner to apply the grammar instantly (Paling, 2017: 147).

When a coachee demonstrates a lack of knowledge regarding a grammatical area or is confused, then a neurolanguage coach must use their expertise as a teacher and introduce new grammar, so he / she starts to teach (Paling, 148). But, introducing some new material, the coach should do it, as was already mentioned, not in a traditional directive teaching style. Here we should again mention a non-directive, quiet, brain-friendly coaching style. And by doing this we ensure that our learners' limbic systemremains calm all the time and thus open to receive and apply new knowledge straight ahead (Paling, 2017: 149).

Powerful questions should be used at all times, not just to stimulate and encourage the conversations within topics, but also as provocations for brain connections / associations and disconnections / disassociations. Let us take a look at examples of such questions:

"How similar is this grammatical issue to the same issue in your language?"

"How is that said in your language?"

"How could you say that in a different way?"

"Can you give me alternatives to that wordmaybe three or four?"
And lastly, clarification. We should use clarification to consolidate what the learner is saying and to clarify what he / she means. It brings clarity to any kind of confusion or misunderstanding or lack of knowledge wherever necessary. Let us consider the following examples of clarification (Paling, 2017: 152):

"So, what you are saying is that..."

"Ah, that means..."

"So, that is to say..."

"If I say this in another way, then..."

Conclusions. Summing up, we should say that we live in a globalised world, in the world of technology and we as language teachers, as educators should be aware of all the challenges nowadays. We should realise that our learners have changed. Our main task is to create a perfect learning state for our learners whether we mean traditional classes or online classes that we have been conducting nowadays throughout the world. In this regard, the key principles of neuroscience, which have been mentioned in this article can really help us do this. Analysing the principles of Neurolanguage Coaching we can definitely apply them in our classrooms, not just remain the teachers who transmit the knowledge. We understand that each brain is different, so we should act like coaches, not just language teachers. So, moving deeper into 21 century, we should face the challenges we encounter in the learning process and should be ready to adapt to the needs of our learners.

\section{BIBLIOGRAPHY}

1. «Half Marathon for Language Educators» (materials from online webinar). URL: https://www. languagecoachingcertification.com/event/free-webinar-half-marathon-for-language-educators/ 2020.

2. Approaches and Methods in language teaching. (Second edition). Jack C, Richards, Theodore S. Rodjers. (Cambridge language teaching library). Jan., 311986.

3. Begley S. Train your mind, change your brain: How a new science reveals our extraordinary potential to transform ourselves. New York: Ballantine Books. 2007. URL: https://www.goodreads.com/book/show/51368.Train_Your_Mind_ Change Your_Brain

4. Futurelearn. URL: https://www.futurelearn.com/courses/understanding-language/3/steps/45925.

5. Gage F. H., Kempermann G. New neural cells for the adult brain. Scientific American 28(5), 1999. Pp. 48-53.

6. Introduction to Neurolanguage Coaching. Online course. URL: https://www.futurelearn.com.

7. Jensen E. Introduction to brain-compatible learning. San Diego, CA: The Brain Store. URL: https://uk.sagepub.com/ en-gb/eur/introduction-to-brain-compatible-learning/book231620.

8. Kelly C. H. The Brain Studies Boom: Using Neuroscience in ESL / EFL Teacher Training. Development (Springer), 2017. Pp. 79-102.

9. Kelly C. Sandy C. Brain-based learning and the active approach. The Language Teacher, 2008. URL: http://www. bbbforlearning.com/uploads/1/0/4/4/10446722/brain_based_learning_is_active_learning.pdf

10. Lieberman M. D. Social: Why our brains are wired to connect. Oxford: Oxford University Press, 2013. URL: https:// psycnet.apa.org/record/2013-09689-000

11. Paling R. M. Neurolanguage coaching. Brain friendly language learning. 2017. URL: https://www.amazon.com/ Neurolanguage-Coaching-Friendly-Language-Learning/dp/1910864943.

12. Skehan P. A cognitive approach to language learning. Oxford: Oxford University Press. 1998. URL: https:// escholarship.org/uc/item/3s $25 \mathrm{j} 29 \mathrm{j}$

13. Teaching with Zoom: Advice from the Brain. The English Connection. (24), 3 Korea TESOL. Vol. 24 , Issue 3, 2020.

14. Understanding Language: Learning and Teaching. URL: https://www.futurelearn.com/courses/understandinglanguage/3/todo/2931,2015

15. Wilson E. O. (2002). The power of story. American Educator, 26(1), p. 8-11. 
Yanyk $O$. The main principles of neuroscience in the context of a "brain-friendly"...

\section{REFERENCES}

1. «Half Marathon for Language Educators» (materials from online webinar). URL: https://www. languagecoachingcertification.com/event/free-webinar-half-marathon-for-language-educators/ 2020.

2. Approaches and Methods in language teaching. (Second edition). Jack C, Richards, Theodore S. Rodjers. (Cambridge language teaching library). Jan., 311986.

3. Begley S. Train your mind, change your brain: How a new science reveals our extraordinary potential to transform ourselves. New York: Ballantine Books. 2007. URL: https://www.goodreads.com/book/show/51368.Train_Your_Mind_ Change Your_Brain

4. Futurelearn. URL: https://www.futurelearn.com/courses/understanding-language/3/steps/45925, 2015.

5. Gage F. H., Kempermann G. New neural cells for the adult brain. Scientific American 28(5), 1999. pp. $48-53$.

6. Introduction to Neurolanguage Coaching. Online course. URL: https://www.futurelearn.com 2020

7. Jensen E. Introduction to brain-compatible learning. San Diego, CA: The Brain Store. URL: https://uk.sagepub.com/ en-gb/eur/introduction-to-brain-compatible-learning/book231620, 1998.

8. Kelly C. H. The Brain Studies Boom: Using Neuroscience in ESL / EFL Teacher Training. Development (Springer). 2017. Pp. 79-102.

9. Kelly C. Sandy C. Brain-based learning and the active approach. - The Language Teacher, 2008. URL: http:// www.bbbforlearning.com/uploads/1/0/4/4/10446722/brain_based_learning_is_active_learning.pdf

10. Lieberman M. D. Social: Why our brains are wired to connect. Oxford: Oxford University Press, 2013. URL: https:// psycnet.apa.org/record/2013-09689-000

11. Paling R. M. Neurolanguage coaching. Brain friendly language learning. URL: https://www.amazon.com/ Neurolanguage-Coaching-Friendly-Language-Learning/dp/1910864943, 2017.

12. Skehan P. A cognitive approach to language learning. Oxford: Oxford University Press. URL: https://escholarship.org/ uc/item/3s25j29j,1998.

13. Teaching with Zoom: Advice from the Brain. The English Connection. (24), 3 Korea TESOL. Vol. 24 , Issue 3, 2020.

14. Understanding Language: Learning and Teaching. URL: https://www.futurelearn.com/courses/understandinglanguage/3/todo/2931,2015

15. Wilson E. O. (2002). The power of story. American Educator, 26(1), p. 8-11. 